\title{
Association study between asthma and single nucleotide polymorphisms of ORMDL3, GSDMB, and ILIRL1 genes in an Algerian population
}

\author{
Mouna Ziani ${ }^{1 *}$ (D, Amanda P. Henry ${ }^{2}$ and lan P. Hall ${ }^{2}$
}

\begin{abstract}
Background: Genetic variation has a key role in the development of asthma, but genetic influences may vary between different populations. In this study, we looked for evidence of association of key asthma SNPs, namely, rs1420101 and rs10192157 within the ILIRL1 gene, rs2305480 in GSDMB gene, and the rs3744246 polymorphism in the ORMDL3 gene, in the Algerian population. We included 266 unrelated subjects of an Algerian population in a case-control study, with 125 adult asthmatic and 141 healthy controls. DNA was extracted and genotypes determined by the Taqman PCR technique for characterization of the different genetic variants.

Results: The results show that there were no significant differences in allele frequencies for 3 of the chosen SNPs in the ORMDL3, GSDMB, and ILIRL1 genes between the asthmatic and control groups with respective $P$ values of $0.922,0.331$, and 0.937 . However the T allele of rs10192157 of the ILIRL1gene was associated with protection from asthma ( $P$ value $=0.010$ )

Conclusion: These results indicate that there is no marked effect of rs3744246, rs2305480, and rs 1420101 polymorphisms of the ORMDL3, GSDMB, and IL1RL1 genes on asthma risk in the Algerian population. However, a protective effect of the rs10192157 polymorphism of the ILIRL1 gene was found.
\end{abstract}

Keywords: Algerian population, Asthma, GSDMB, IL1RL1, ORMDL3, Polymorphism

\section{Background}

Asthma is a serious global health problem that affects all age groups. An estimated 300 million people in the world suffer from asthma. That number is expected to reach 400 million by 2025 as countries become more urbanized [1-3]. Asthma is defined by the Global Initiative for Asthma (GINA) as a heterogeneous disease, usually characterized by chronic airway inflammation. Typically respiratory symptoms such as wheeze, shortness of breath, chest tightness, and cough vary over time and in

\footnotetext{
*Correspondence: zianimouna83@gmail.com

'Biology Department, Faculty of Nature and Life Sciences, Hassiba Benbouali University of Chlef, BP 151, Hay Es Salem, 02000 Chlef, Algeria

Full list of author information is available at the end of the article
}

intensity, and patients display variable expiratory airflow limitation [3].

Previous meta-analyses and genome wide association studies used in the investigation of asthma susceptibility genes have identified multiple single-nucleotide polymorphisms (SNPs) and loci associated with asthma in large populations of thousands of individuals in different ethnicities. Asthma susceptibility genes identified using this approach include IL1RL1, ORMDL3, SMAD3, IL-33, IL18R, TSLP, PDE4D, MHC II, DQ, IKZF4, STAT6, GATA3, LRRC32, GSDMB, PEX14, IL6R, PYHIN1, and IL2RB [4-11].

Many studies have shown that polymorphism in the 17q12-21 locus harboring the Orosomucoid-like 3 $(O R M D L 3)$ and gasdermin B (GSDMB) genes are 
associated with asthma. The first exploration of the association of $O R M D L$ sphingolipid biosynthesis regulator 3 (ORMDL3) gene with asthma was in 2007 [4]. This association has been confirmed in different ethnicities [12, 13]. ORMDL3 gene encodes ORM1-like 3, a transmembrane protein of the endoplasmic reticulum, and a member of the family of orosomucoid-like proteins, which is produced in a number of cells, including lymphocytes and liver cells. ORM proteins regulate sphingolipid production, and altered expression of ORM genes or mutations affecting their phosphorylation sites can result in deregulation of sphingolipid production [13, 14]. ORMDL3 is involved in the development of the unfolded protein response, a process that can activate inflammation $[15,16]$ and T-lymphocyte induction [17, 18], which may explain the reported association between ORMDL3 gene with asthma [13, 19].

The ORMDL3 gene contains several single nucleotide polymorphisms (SNPs) which may be involved in the regulation of its expression. However, these are in strong linkage disequilibrium (LD) with SNPs in genes located in the same LD block as ORMDL3 on chromosome $17 \mathrm{q} 21$ (e.g., IKZF3, ZPBP2, and GSDMB) which were also significantly associated with asthma [4, 20-22]. Divergent results had also been reported for the rs3744246 polymorphism of the ORMDL3 gene with asthma in different populations $[4,13]$.

Within the GSDMB gene, rs 2305480 is in the same linkage disequilibrium block as rs8076131, rs12603332 of ORMDL3 gene that have been reported to be associated with asthma in different populations [12, 23-27].

Interleukin-1 receptor-like 1 (IL1RL1) gene is situated in chromosome 2q11 encoding two forms of the suppression of tumorigenicity 2 receptor (ST2), a membrane-bound protein (ST2L) and a soluble form (sST2) $[28,29]$. Two major transcript variants are produced from the IL1RL1 gene [28]. The transmembrane form of ST2 is a long transcript selectively expressed on Th2- but not Th1-type $\mathrm{T}$ cells and binding of interleukine-33 (IL-33), induces Th2 immune responses [30, 31]. The transcript variant 2 is short and encodes a soluble decoy receptor (sST2) for IL-33 [32]. ST2 transcripts can be expressed from two spatially distinct promoters. The distal promoter can drive either ST2L or sST2 expression, while the proximal promoter directs expression of sST2 only [29, 33].

The ST2/IL-33 signaling pathway participates in type 2 immune responses and the pathophysiology of related diseases including asthma [29, 34-36]. Genetic variation in IL1RL1 genes has been reported to be strongly associated with asthma in the main genome-wide association studies (GWAS) and meta-analysis to date [6, 22, 37-40].

In this study, we investigate the asthma association signal of different SNPs, rs1420101 and rs10192157 within IL1RL1 gene, rs2305480 in GSDMB gene, and the rs3744246 polymorphism of ORMDL3 gene in the Algerian population.

\section{Methods \\ Study populations}

We included 266 unrelated subjects of an Algerian population from the city of Chlef in a case-control study. We recruited 125 adult patients diagnosed asthmatic, and 141 unrelated healthy controls matched to cases by ethnicity and geographic region. Healthy controls had neither first-degree relatives with asthma nor history of asthma or atopy at the time of recruitment. A questionnaire [41], spirometry reading and blood samples were obtained from all participants including patients and controls after their written informed consent. Genomic DNA was extracted from peripheral blood leukocytes by using the salting out method [42].Our study followed the standards and recommendations of the Declaration of Helsinki.

\section{Genetic analyses}

We selected four key single nucleotide polymorphisms (SNPs) based on previous studies according and linkage disequilibrium (LD) patterns. The rs3744246, rs2305480, rs1420101, and rs10192157 polymorphism of ORMDL3, GSDMB, and IL1RL1genes respectively, were genotyped by Taqman PCR. Assays were carried out in a 96-well format using $10 \mathrm{ng}$ of DNA. Allelic discrimination assays were performed in duplicate in $25 \mu \mathrm{L}$ reaction volumes using approximately: $2 \mu \mathrm{L}$ of total DNA per assay, 12.5 $\mu \mathrm{L}$ of genotyping Master Mix (TaqManlife technologies), $1.25 \mu \mathrm{L}$ of the predesigned SNP genotyping assay provided by Applied Biosystems, and TE buffer to make up $25 \mu \mathrm{L}$ total volume.

The allele discrimination assay was performed using a Taqman $^{\circ}$ MX3005P machine and using the allele discrimination set up. Before the first cycle, a $10 \mathrm{~min}$ initial denaturation cycle was carried out at $95{ }^{\circ} \mathrm{C}$. Each cycle consisted of denaturation at $95{ }^{\circ} \mathrm{C}$ for $30 \mathrm{~s}$ followed by annealing for $1 \mathrm{~min}$ at $60{ }^{\circ} \mathrm{C}$. Genotyping of the amplified PCR products was based on the differences in HEX (VIC) and FAM fluorescent levels. The data provided by the machine was quality controlled to ensure correct calling of SNPs by setting the threshold lines, and the last cycle was set to 35 to ensure specificity.

\section{Statistical analysis}

Genotype and allele frequencies were compared using the SPSS version 21.0 software (Statistical Package for the Social Sciences, Inc., Chicago, Illinois, USA). The association of the SNPs and asthma were determined by the standard chi-squared test $(\chi 2)$. Statistical significance was set at $P<0.05$.Odds ratios (OR) with $95 \%$ confidence 
intervals $(95 \% \mathrm{CI})$ were also calculated using the SPSS 21 software. Correction for multiple testing was carried out using the Bonferroni Holm adjustment. The significance threshold for the $P$ value was set at $0.0125(0.05 / 4$ considering 4 SNPs tested). Deviation from the HardyWeinberg equilibrium was examined with the $X^{2}$ test. Study power was assessed using the Genetic Association study Power Calculator (GAS) [43].

\section{Results}

\section{Subject characteristics}

Table 1 lists the characteristics of the enrolled subjects. The asthmatic subjects had a reduced spirometry (FVC, FEV1). The control subjects were slightly younger. A significant difference in terms of gender was observed in the asthmatic population and the control population with a $P$ value $=0.011, X^{2}=6.442$, and $\mathrm{OR}=0.53,95 \% \mathrm{CI}$ $[(0.318-0.894)]$.

\section{Genotypes and allele frequencies}

To study the impact of the rs3744246, rs2305480, rs1420101, and rs10192157 polymorphism of the ORMDL3, GSDMB, and IL1RL1 genes on the risk of asthma development in an Algerian population of the city of Chlef, we compared the genotype and allelic frequencies characterized in all 266 subjects. The genotype distributions of all SNPs were in Hardy-Weinberg equilibrium. Given the number of subjects, the study had limited power $(60-70 \%$ for each SNP) to identify anything other than a large effect size for these SNPs.

\section{Association of ORMDL3 and GSDMB genes (rs3744246, rs2305480) with asthma prevalence}

The distribution of the different genotypes of the rs3744246 and rs2305480 polymorphism among the two groups reveals no significant statistical difference (Tables 2 and 3) which suggests that there is no strong association between rs3744246 and rs2305480 polymorphism of the ORMDL3 and GSDMB genes and asthma in the Algerian population.

Table 1 Clinical characteristics of the subjects enrolled in the present study (data are mean \pm SD)

\begin{tabular}{lll}
\hline Characteristics & Patients & Controls \\
\hline No. of subjects & 125 & 141 \\
Age (years) & $42.43 \pm 15.76$ & $32.92 \pm 9.39$ \\
Sex (male/female) & $55 / 70$ & $84 / 57$ \\
FVC (\% predicted), mean \pm SD & $67.8 \pm 17.1$ & $106.2 \pm 10.8$ \\
FEV1 (\% predicted), mean $\pm S D$ & $56.5 \pm 16.7$ & $105.6 \pm 11.3$
\end{tabular}

FVC forced vital capacity, FEV1 forced expiratory volume in $1 \mathrm{~s}$
Table 2 The distribution of rs3744246 (ORMDL3 gene) polymorphism genotype and allele frequencies in the Algerian population studied

\begin{tabular}{|c|c|c|}
\hline Genotypes & $\begin{array}{l}\text { Asthmatic } \\
N=125\end{array}$ & $\begin{array}{l}\text { Control } \\
N=141\end{array}$ \\
\hline CC & $62.4 \%(78)$ & $65.95 \%(93)$ \\
\hline CT & $29.6 \%(37)$ & $23.40 \%(33)$ \\
\hline$\pi$ & $8.0 \%(10)$ & $10.64 \%(15)$ \\
\hline Significance & \multicolumn{2}{|l|}{$\begin{array}{l}X^{2}=1.588 \\
P \text { value }=0.452\end{array}$} \\
\hline \multicolumn{3}{|l|}{ Alleles } \\
\hline C & $76.8 \%(96)$ & $77.3 \%(109)$ \\
\hline $\mathrm{T}$ & $23.2 \%(29)$ & $22.7 \%(32)$ \\
\hline Significance & \multicolumn{2}{|l|}{$\begin{array}{l}X^{2}=0.010 \\
P \text { value }=0.922\end{array}$} \\
\hline Odds ratio ( $95 \%$ confidence interval) & \multicolumn{2}{|l|}{$0.97(0.527-1.798)$} \\
\hline
\end{tabular}

Association of IL1RL1 gene (rs1420101 and rs10192157) with asthma prevalence

The frequencies distribution of the rs1420101 polymorphism genotype of the IL1RL1 gene between the asthmatics and the controls are shown in Table 4. No significant differences were observed in this distribution between the asthma and control groups (Table 4).

However, for the rs10192157 polymorphism, a significant protective effect (decreased risk for asthma) was seen for the $\mathrm{T}$ allele (Table 5 ). The odds ratio (OR) was $1.89(95 \% \mathrm{CI}=1.127-3.167)$ in the Algerian population.

\section{Discussion}

Asthma is a complex disease and a number of asthma susceptibility genes have been identified. However the complex etiology, combined with extensive heterogeneity, has made genetic studies of asthma challenging. In the present study, we investigated the relationship

Table 3 The distribution of rs2305480 (GSDMB gene) polymorphism genotype and allele frequencies in the Algerian population studied

\begin{tabular}{lll}
\hline Genotypes & $\begin{array}{l}\text { Asthmatic } \\
N=125\end{array}$ & $\begin{array}{l}\text { Control } \\
N=141\end{array}$ \\
\hline AA & $41.6 \%(52)$ & $47.51 \%(67)$ \\
AG & $42.4 \%(53)$ & $41.84 \%(59)$ \\
GG & $16.0 \%(20)$ & $10.64 \%(15)$ \\
Significance & $X^{2}=1.971$ & \\
& $P$ value $=0.373$ & \\
Alleles & & \\
\multicolumn{1}{c}{ A } & & \\
\multicolumn{1}{c}{ G } & $62.4 \%(78)$ & $68.08 \%(96)$ \\
Significance & $37.6 \%(47)$ & $31.92 \%(45)$ \\
& $X^{2}=0.947$ & \\
Odds ratio (95\% confidence interval) & $\mathbf{P}$ value =0.331 \\
\hline
\end{tabular}


Table 4 The distribution of rs1420101 (ILIRL1 gene) polymorphism genotype and allele frequencies in the Algerian population studied

\begin{tabular}{|c|c|c|}
\hline Genotypes & Asthmatic $N=125$ & Control $N=141$ \\
\hline$\overline{T T}$ & $23.2 \%(29)$ & $28.37 \%(40)$ \\
\hline$C T$ & $57.6 \%(72)$ & $48.23 \%(68)$ \\
\hline CC & $19.2 \%(24)$ & $23.40 \%(33)$ \\
\hline Significance & $X^{2}=2.335 P$ value $=0.311$ & \\
\hline \multicolumn{3}{|l|}{ Alleles } \\
\hline T & $52.0 \%(65)$ & $52.48 \%(74)$ \\
\hline C & $48.0 \%(60)$ & $47.52 \%(67)$ \\
\hline Significance & $X^{2}=0.006 P$ value $=0.937$ & \\
\hline Odds ratio (95\% confidence interval) & $0.98(0.589-1.635)$ & \\
\hline
\end{tabular}

between the rs3744246, rs2305480, rs1420101, and rs10192157 within the ORMDL3, GSDMB, and IL1RL1 genes in adult asthmatic patients and controls of an Algerian population. The majority of studies on these SNPs and their relationship to asthma have been undertaken in European populations, but no studies have been reported to date in the Algerian population.

Several GWAS for asthma have identified ORMDL3/ GSDMB genes at the $17 \mathrm{q} 21$ locus as an asthma candidate gene locus, and subsequent studies have confirmed the association of polymorphisms in this chromosome region with asthma in different ethnic groups [4, 11, 13, 21, 44-48].

In the present study, no evidence for a strong association of the rs3744246, rs2305480 polymorphisms for the ORMDL3/GSDMB genes was found with the asthma in an Algerian population. This is in contrast with several studies which have reported an association of different SNPs in the ORMDL3/GSDMB with asthma [4, 6, $12,47,49$ ] and also a strong association with variation in the expression of ORMDL3 [4] and GSDMB genes [50,

Table 5 The distribution of rs10192157 (IL1RL1 gene) polymorphism genotype and allele frequencies in the Algerian population studied

\begin{tabular}{lll}
\hline Genotypes & $\begin{array}{l}\text { Asthmatic } \\
N=125\end{array}$ & $\begin{array}{l}\text { Control } \\
N=141\end{array}$ \\
\hline CC & $35.2 \%(44)$ & $39.7 \%(56)$ \\
$C T$ & $44.8 \%(56)$ & $22.0 \%(31)$ \\
$\Pi T$ & $20.0 \%(25)$ & $38.3 \%(54)$ \\
Significance & $X^{2}=18.374$ & \\
& $P$ value $=0.0001$ & \\
Alleles & & \\
\multicolumn{1}{c}{ C } & & \\
$T$ & $57.6 \%(72)$ & $41.8 \%(59)$ \\
Significance & $42.4 \%(53)$ & $58.2 \%(82)$ \\
& $\begin{array}{l}X^{2}=6.581 \\
P \text { value=0.010 }\end{array}$ \\
Odds ratio (95\% confidence interval) & $1.89(1.127-3.167)$ \\
\hline
\end{tabular}

51]. Two meta-analyses of GWAS in European [6] and Puerto Rican populations [22] reported a specific association to childhood-onset asthma with the rs2305480 of GSDMB gene; in addition, similar results were reported in the UK cohort consisting of 370 families with at least two asthmatic children [26]. This difference between the previous studies and our study on rs2305480 may reflect lack of power in the current study although it might also be because childhood asthma likely has genetic determinants that differ from those of adult-onset asthma. Conflicting association studies results have been reported for rs3744246 of the ORMDL3 gene in other populations as well. For example, in a study by Galanter et al. [12], African Americans and Mexicans showed a negative association for rs3744246 polymorphism of ORMDL3. Moffatt et al. [4] genotyped healthy children and patients with childhood onset asthma from Germany and the UK. In their study, the German patients demonstrate an association of rs3744246 and asthma, a contrasting result was reported with the UK patients. In two previous studies $[24,27]$ on Chinese populations no significant differences was reported in the distribution of the genotype and allele frequencies of the rs3744246 between asthma patients and controls. Furthermore, a cumulative metaanalysis over time showed no significant association for rs3744246 [13].

Interleukin 1 receptor-like 1 (IL1RL1) plays a significant role in immune/inflammatory disorders such as asthma [36]. SNPs spanning IL1RL1 have reproducibly been associated with asthma susceptibility in the main GWA studies [6, 7, 37, 38, 52]. The IL1RL1 SNPs associated with asthma vary between studies although are mostly located in the ILIRL1 5' region, and have been demonstrated to influence the levels of expression of the soluble form of ST2 in serum [33]. Our study showed no significant association of the rs1420101 with asthma in the Algerian population; however, a protective effect of the rs10192157 polymorphism was found. Similar results were found for rs1420101 in children for Dutch 
population, where no association was reported with asthma [33, 53]. Again, the failure to identify association with rs1420101 may be due to lack of power. Association of rs1420101 and rs10192157 with asthma were also studied in the Dutch Asthma Genome-wide Association Study cohort and three European birth cohorts, BAMSE (Children/Barn, Allergy, Milieu, Stockholm, an epidemiological survey), INMA (Infancia y MedioAmbiente) and PIAMA (Prevention and Incidence of Asthma and Mite Allergy) [40, 54]. Rs10192157 is situated in the coding region variation in Toll/interleukin-1 receptor (TIR) domain, and it has been suggested that protein structure may be altered in carriers of these asthma risk genotype $[6,8,40]$. Recently, a new study based on the SNP data obtained from re-sequencing and genetic association analysis in the Dutch Asthma GWAS (DAG) cohort, Genetics of Asthma Severity and Phenotypes (GASP) cohort, combined analyses of both GASP/ DAG cohorts and MAAS cohort, reported that the rs10192157 C allele was associated with a decrease in combined and soluble IL1RL1 mRNA [55].

One potential weakness of this study is that the controls were slightly younger than the cases. However, this would not account for the positive association that was seen with rs10192157. New cases of asthma after the age of 30 are uncommon in Algeria, and hence, we think this is unlikely to account for our inability to identify potential associations between risk alleles and asthma.

\section{Conclusions}

This is the first study in the Algerian population to assess the relevance of these polymorphisms in known asthma candidate genes to asthma risk. This study shows a protective effect of the $\mathrm{T}$ allele of rs10192157 of IL1RL1 gene where it decreased risk for asthma, but no association was found for the rs3744246, rs2305480, and rs1420101 variants with asthma in the Algerian population. Understanding the relevance of polymorphic variants in different ethnic groups is important to fully characterize the contribution of genetic variants to asthma risk overall. More studies in larger populations are needed to confirm our results.

\section{Abbreviations}

Cl: Confidence interval; FEV1: Forced expiratory volume in 1s; FVC: Forced vital capacity; GSDMB: Gasdermin B; ILIRL1: Interleukin 1 receptor-like 1; OR: Odds ratio; ORMDL3: Orosomucoid-like 3; P value: Probability; SPSS: Statistical Package for the Social Sciences

\section{Acknowledgements}

The authors would like to thank all participants of the study.

\section{Authors' contributions}

$\mathrm{MZ}$ contributed in the study design; data collection; performed experiments and analysis; and in manuscript preparation. $\mathrm{H}$ supervised the research and performed manuscript revision. $\mathrm{AH}$ is the advisor on the performed experiments. All authors read and approved the final manuscript.

\section{Funding}

This work was accomplished by a grant from Nottingham University, UK, and by Hassiba Benbouali University-Chlef, Algeria. They supported us by providing the reagents and the equipment necessary to the study of this association.

\section{Availability of data and materials}

The datasets used and/or analyzed during the current study are available from the corresponding author on reasonable request.

\section{Declarations}

Ethics approval and consent to participate

A written informed consent was attributed by all participants of the study and a scientific approval was given by the scientific council of the Faculty of Sciences of Nature and Life (state no. 04/2017) of Hassiba Benbouali University-Chlef, Algeria.

\section{Consent for publication}

Not applicable

\section{Competing interests}

The authors declare that they have no competing interests.

\section{Author details}

${ }^{1}$ Biology Department, Faculty of Nature and Life Sciences, Hassiba Benbouali University of Chlef, BP 151, Hay Es Salem, 02000 Chlef, Algeria. ${ }^{2}$ Division of Respiratory Medicine, Queen's Medical Centre, University of Nottingham, Derby Rd, Lenton, Nottingham NG7 2UH, UK.

Received: 2 January 2021 Accepted: 25 March 2021

Published online: 10 May 2021

\section{References}

1. Masoli M, Fabian D, Holt S, Beasley R (2004) Global Initiative for Asthma (GINA) Program. The global burden of asthma: executive summary of the GINA Dissemination Committee report. Allergy 59:469-478. https://doi.org/1 0.1111/j.1398-9995.2004.00526.x

2. To T, Stanojevic S, Moores G, Gershon AS, Bateman ED, Cruz AA, Boulet LP (2012) Global asthma prevalence in adults: findings from the cross-sectional world health survey. BMC Public Health 12(1):204. https://doi.org/10.1186/14 71-2458-12-204

3. Reddel HK, Bateman ED, Becker A, Boulet LP, Cruz AA, Drazen JM, Haahtela T, Hurd SS, Inoue H, de Jongste JC, Lemanske RF Jr, Levy ML, O'Byrne PM, Paggiaro P, Pedersen SE, Pizzichini E, Soto-Quiroz M, Szefler SJ, Wong GWK, FitzGerald JM (2015) A summary of the new GINA strategy: a roadmap to asthma control. Eur Respir J 46(3):622-639. https://doi.org/10.1183/13993 003.00853-2015

4. Moffatt MF, Kabesch M, Liang L, Dixon AL, Strachan D, Heath S, Depner M, von Berg A, Bufe A, Rietschel E, Heinzmann A, Simma B, Frischer T, WillisOwen SAG, Wong KCC, Illig T, Vogelberg C, Weiland SK, von Mutius E, Abecasis GR, Farrall M, Gut IG, Lathrop GM, Cookson WOC (2007) Genetic variants regulating ORMDL3 expression contribute to the risk of childhood asthma. Nature. 448(7152):470-473. https://doi.org/10.1038/nature06014

5. Himes BE, Hunninghake GM, Baurley JW, Rafaels NM, Sleiman P, Strachan DP, Wilk JB, Willis-Owen SAG, Klanderman B, Lasky-Su J, Lazarus R, Murphy AJ, Soto-Quiros ME, Avila L, Beaty T, Mathias RA, Ruczinski I, Barnes KC, Celedón JC, Cookson WOC, Gauderman WJ, Gilliland FD, Hakonarson H, Lange C, Moffatt MF, O'Connor GT, Raby BA, Silverman EK, Weiss ST (2009) Genome-wide association analysis identifies PDE4D as an asthmasusceptibility gene. Am J Hum Genet 84(5):581-593. https://doi.org/10.1016/ j.ajhg.2009.04.006

6. Moffatt MF, Gut IG, Demenais F, Strachan DP, Bouzigon E, Heath S, von Mutius E, Farrall M, Lathrop M, Cookson WOCM (2010) A large-scale, consortium-based genomewide association study of asthma. N Engl J Med 363(13):1211-1221. https://doi.org/10.1056/NEJMoa0906312

7. Ferreira MA, Mcrae AF, Medland SE, Nyholt DR, Gordon SD, Wright MJ et al (2011) Association between ORMDL3, IL1RL1and a deletion on chromosome 17q21 with asthma risk in Australia. Eur J Hum Genet 19(4): 458-464. https://doi.org/10.1038/ejhg.2010.191 
8. Portelli M, Sayers I (2012) Genetic basis for personalized medicine in asthma. Expert Rev Respir Med 6(2):223-236. https://doi.org/10.1586/ers.12.9

9. Ferreira MA, Matheson MC, Tang CS, Granell R, Ang W, Hui J, Kiefer AK, Duffy DL, Baltic S, Danoy P, Bui M, Price L, Sly PD, Eriksson N, Madden PA, Abramson MJ, Holt PG, Heath AC, Hunter M, Musk B, Robertson CF, le Souëf P, Montgomery GW, Henderson AJ, Tung JY, Dharmage SC, Brown MA, James A, Thompson PJ, Pennell C, Martin NG, Evans DM, Hinds DA, Hopper JL, Australian Asthma Genetics Consortium Collaborators (2014) Genomewide association analysis identifies 11 risk variants associated with the asthma with hay fever phenotype. J Allergy Clin Immunol 133(6):1564-1571. https://doi.org/10.1016/j.jaci.2013.10.030

10. Almoguera B, Vazquez L, Mentch F, Connolly J, Pacheco JA, Sundaresan AS et al (2017) Identification of four novel loci in asthma in European American and African American populations. Am J Respir Crit Care Med 195:456-463. https://doi.org/10.1164/rccm.201604-08610C

11. Demenais F, Margaritte-Jeannin P, Barnes KC, Cookson WOC, Altmüller J, Ang W et al (2018) Multiancestry association study identifies new asthma risk loci that colocalize with immune-cell enhancer marks. Nat Genet 50(1): 42-53. https://doi.org/10.1038/s41588-017-0014-7

12. Galanter J, Choudhry S, Eng C, Nazario S, Rodríguez-Santana JR, Casal J et al (2008) ORMDL3 gene is associated with asthma in three ethnically diverse populations. Am J Respir Crit Care Med 177:1194-2000. https://doi.org/10.11 64/rccm.200711-1644OC

13. Zhao CN, Fan Y, Huang JJ, Zhang HX, Gao T, Wang C, Wang T, Hou LF (2015) The association of GSDMB and ORMDL3 gene polymorphisms with asthma: a meta-analysis. Allergy, Asthma Immunol Res 7(2):175-185. https:// doi.org/10.4168/aair.2015.7.2.175

14. Breslow DK, Collins SR, Bodenmiller B, Aebersold R, Simons K, Shevchenko A, Ejsing CS, Weissman JS (2010) Orm family proteins mediate sphingolipid homeostasis. Nature. 463(7284):1048-1053. https://doi.org/10.1038/na ture08787

15. Todd DJ, Lee AH, Glimcher LH (2008) The endoplasmic reticulum stress response in immunity and autoimmunity. Nat Rev Immunol 8(9):663-674. https://doi.org/10.1038/nri2359

16. Zhang K, Kaufman RJ (2008) From endoplasmic-reticulum stress to the inflammatory response. Nature. 454(7203):455-462. https://doi.org/10.1038/ nature07203

17. Weber KS, Miller MJ, Allen PM (2008) Th17 cells exhibit a distinct calcium profile from Th1 and Th2 cells and have Th1-like motility and NF-AT nuclear localization. J Immunol 180(3):1442-1450. https://doi.org/10.4049/ jimmunol.180.3.1442

18. Carreras-Sureda A, Cantero-Recasens G, Rubio-Moscardo F, Kiefer K, Peinelt C, Niemeyer BA, Valverde MA, Vicente R (2013) ORMDL3 modulates storeoperated calcium entry and lymphocyte activation. Hum Mol Genet 22(3): 519-530. https://doi.org/10.1093/hmg/dds450

19. Cantero-Recasens G, Fandos C, Rubio-Moscardo F, Valverde MA, Vicente R (2010) The asthma-associated ORMDL3 gene product regulates endoplasmic reticulum-mediated calcium signaling and cellular stress. Hum Mol Genet 19(1):111-121. https://doi.org/10.1093/hmg/ddp471

20. Hirota T, Harada M, Sakashita M, Doi S, Miyatake A, Fujita K et al (2008) Genetic polymorphism regulating ORM1-like 3 (Saccharomyces cerevisiae) expression is associated with childhood atopic asthma in a Japanese population. J Allergy Clin Immunol 121:769-770. https://doi.org/10.1016/j.ja ci.2007.09.038

21. Tavendale R, Macgregor DF, Mukhopadhyay S, Palmer CN (2008) A polymorphism controlling ORMDL3 expression is associated with asthma that is poorly controlled by current medications. J Allergy Clin Immunol 121(4):860-863. https://doi.org/10.1016/j.jaci.2008.01.015

22. Yan Q, Brehm J, Pino-Yanes M, Forno E, Lin J, Oh SS et al (2017) A metaanalysis of genome-wide association studies of asthma in Puerto Ricans. Eur Respir J 49:pii1601505. https://doi.org/10.1183/13993003.01505-2016

23. Hrdlickova B, Holla LI (2011) Relationship between the 17q21 locus and adult asthma in a Czech population. Hum Immunol 72(10):921-925. https:// doi.org/10.1016/j.humimm.2011.07.309

24. Yang FF, Huang Y, Li QB, Dai JH, Fu Z (2012) Single nucleotide polymorphisms in the ORM1-like 3 gene associated with childhood asthma in a Chinese population. Genet Mol Res 11(4):4646-4653. https://doi.org/1 0.4238/2012.October.19.1

25. Li FX, Tan JY, Yang XX, Wu YS, Wu D, Li M (2012) Genetic variants on $17 q 21$ are associated with asthma in a Han Chinese population. Genet Mol Res 11(1):340-347. https://doi.org/10.4238/2012.February.10.5
26. Tulah AS, Holloway JW, Sayers I (2013) Defining the contribution of SNPS identified in asthma GWAS to clinical variables in asthmatic children. BMC Med Genet 14:100. https://doi.org/10.1186/1471-2350-14-100

27. Leung TF, Sy HY, Ng MC, Chan IH, Wong GW, Tang NL et al (2009) Asthma and atopy are associated with chromosome 17q21 markers in Chinese children. Allergy. 64(4):621-628. https://doi.org/10.1111/j.1398-9995.2008.01 873.x

28. I wahana H, Yanagisawa K, Ito-Kosaka A, Kuroiwa K, Tago K, Komatsu N, Katashima R, Itakura M, Tominaga SI (1999) Different promoter usage and multiple transcription initiation sites of the interleukin-1 receptor-related human ST2 gene in UT-7 and TM12 cells. Eur J Biochem 264(2):397-306. https://doi.org/10.1046/j.1432-1327.1999.00615.x

29. Ho JE, Chen WY, Chen MH, Larson MG, McCabe EL, Cheng S et al (2013) Common genetic variation at the ILIRL1 locus regulates IL-33/ST2 signaling. J Clin Invest 123:4208-4218. https://doi.org/10.1172/JCl67119

30. Oboki K, Ohno T, Kajiwara N, Arae K, Morita H, Ishii A, Nambu A, Abe T, Kiyonari H, Matsumoto K, Sudo K, Okumura K, Saito H, Nakae S (2010) IL-33 is a crucial amplifier of innate rather than acquired immunity. Proc Natl Acad Sci U S A 107(43):18581-18586. https://doi.org/10.1073/pnas.10030591 07

31. Miller AM (2011) Role of IL-33 in inflammation and disease. J Inflamm (Lond) 8:22. https://doi.org/10.1186/1476-9255-8-22

32. Arend WP, Palmer G, Gabay C (2008) IL-1, IL-18, and IL-33 families of cytokines. Immunol Rev 223(1):20-38. https://doi.org/10.1111/j.1600-065X.2 008.00624.x

33. Savenije OE, Kerkhof M, Reijmerink NE, Brunekreef B, de Jongste JC, Smit HA et al (2011) Interleukin-1 receptor-like 1 polymorphisms are associated with serum IL1RL1-a, eosinophils, and asthma in childhood. J Allergy Clin Immunol 127(3):750-760. https://doi.org/10.1016/j.jaci.2010.12.014

34. Schmitz J, Owyang A, Oldham E, Song Y, Murphy E, McClanahan TK et al (2005) IL-33, an interleukin-1-like cytokine that signals via the IL-1 receptorrelated protein ST2 and induces Thelper type 2-associated cytokines. Immunity. 23(5):479-490. https://doi.org/10.1016/j.immuni.2005.09.015

35. Kondo Y, Yoshimoto T, Yasuda K, Futatsugi-Yumikura S, Morimoto M, Hayashi N, Hoshino T, Fujimoto J, Nakanishi K (2008) Administration of IL-33 induces airway hyperresponsiveness and goblet cell hyperplasia in the lungs in the absence of adaptive immune system. Int Immunol 20(6):791800. https://doi.org/10.1093/intimm/dxn037

36. Kurowska-Stolarska M, Kewin P, Murphy G, Russo RC, Stolarski B, Garcia CC et al (2008) IL-33 induces antigen-specific IL-5+ T cells and promotes allergic-induced airway inflammation independent of IL-4. J Immunol 181: 4780-4790. https://doi.org/10.4049/jimmunol.181.7.4780

37. Gudbjartsson DF, Bjornsdottir US, Halapi E, Helgadottir A, Sulem P, Jonsdottir GM et al (2009) Sequence variants affecting eosinophil numbers associate with asthma and myocardial infarction. Nat Genet 41:342-347. https://doi.org/10.1038/ng.323

38. Torgerson DG, Ampleford EJ, Chiu GY, Gauderman WJ, Gignoux CR, Graves PE et al (2011) Meta-analysis of genome-wide association studies of asthma in ethnically diverse North American populations. Nat Genet 43(9):887-892. https://doi.org/10.1038/ng.888

39. Gordon ED, Palandra J, Wesolowska-Andersen $A$, Ringel L, Rios CL, Lachowicz-Scroggins ME et al (2016) IL1RL1 asthma risk variants regulate airway type 2 inflammation. JCl Insight 1:e87871. https://doi.org/10.1172/jci. insight.87871

40. Dijk FN, Xu C, Melén E, Carsin AE, Kumar A, Nolte IM, et al. Genetic regulation of IL1RL1 methylation and IL1RL1-a protein levels in asthma. Eur Respir J. 2018; 51. pii: 1701377. doi: https://doi.org/10.1183/13993003.013 77-2017.

41. GINA. Global strategy for asthma management and prevention. 2009; https://ginasthma.org/wp-content/uploads/2019/01/2010-GINA.pdf.

42. Miller SA, Dykes DD, Polesky HF (1988) A simple salting out procedure for extracting DNA from human nucleated cells. Nucleic Acids Res 16:12-15. https://doi.org/10.1093/nar/16.3.1215

43. Skol AD, Scott L, Abecasis GR, Boehnke M (2006) Joint analysis is more efficient than replication-based analysis for two-stage genome-wide association studies. Nat Genet 38(2):209-213. https://doi.org/10.1038/ng1706

44. Bouzigon E, Corda E, Aschard H, Dizier MH, Boland A, Bousquet J, Chateigner N, Gormand F, Just J, le Moual N, Scheinmann P, Siroux V, Vervloet D, Zelenika D, Pin I, Kauffmann F, Lathrop M, Demenais F (2008) Effect of 17q21 variants and smoking exposure in early-onset asthma. N Engl J Med 359(19):1985-1994. https://doi.org/10.1056/NEJMoa0806604 
45. Madore AM, Tremblay K, Hudson TJ, Laprise C (2008) Replication of an association between 17q21 SNPs and asthma in a French-Canadian familial collection. Hum Genet 123(1):93-95. https://doi.org/10.1007/s00439-0070444-x

46. Sleiman PM, Annaiah K, Imielinski M, Bradfield JP, Kim CE, Frackelton EC et al (2008) ORMDL3 variants associated with asthma susceptibility in North Americans of European ancestry. J Allergy Clin Immunol 122:1225-1227. https://doi.org/10.1016/j.jaci.2008.06.041

47. Wu H, Romieu I, Sienra-Monge JJ, Li H, del Rio-Navarro BE, London SJ (2009) Genetic variation in ORM1-like 3 (ORMDL3) and gasdermin-like (GSDML) and childhood asthma. Allergy. 64(4):629-635. https://doi.org/10.1111/j.13 98-9995.2008.01912.x

48. Wan YI, Shrine NRG, Soler Artigas M, Wain LV, Blakey JD, Moffatt MF, Bush A, Chung KF, Cookson WOCM, Strachan DP, Heaney L, al-Momani BAH, Mansur AH, Manney S, Thomson NC, Chaudhuri R, Brightling CE, Bafadhel M, Singapuri A, Niven R, Simpson A, Holloway JW, Howarth PH, Hui J, Musk AW, James AL, the Australian Asthma Genetics Consortium, Brown MA, Baltic S, Ferreira MAR, Thompson PJ, Tobin MD, Sayers I, Hall IP (2012) Genome-wide association study to identify genetic determinants of severe asthma. Thorax. 67(9):762-768. https://doi.org/10.1136/thoraxjnl-2011-2012 62

49. Bisgaard H, Bønnelykke K, Sleiman PM, Brasholt M, Chawes B, Kreiner-Møller E et al (2009) Chromosome 17q21 gene variants are associated with asthma and exacerbations but not atopy in early childhood. Am J Respir Crit Care Med 179(3):179-185. https://doi.org/10.1164/rccm.200809-14360C

50. Cookson W, Liang L, Abecasis G, Moffatt M, Lathrop M (2009) Mapping complex disease traits with global gene expression. Nat Rev Genet 10(3): 184-194. https://doi.org/10.1038/nrg2537

51. Verlaan DJ, Berlivet $S$, Hunninghake GM, Madore AM, Larivière $M$, Moussette S, Grundberg E, Kwan T, Ouimet M, Ge B, Hoberman R, Swiatek M, Dias J, Lam KCL, Koka V, Harmsen E, Soto-Quiros M, Avila L, Celedón JC, Weiss ST, Dewar K, Sinnett D, Laprise C, Raby BA, Pastinen T, Naumova AK (2009) Allele-specific chromatin remodeling in the ZPBP2/GSDMB/ORMDL3 locus associated with the risk of asthma and autoimmune disease. Am J Hum Genet 85(3):377-393. https://doi.org/10.1016/j.ajhg.2009.08.007

52. Reijmerink NE, Postma DS, Bruinenberg M, Nolte IM, Meyers DA, Bleecker ER, Koppelman GH (2008) Association of IL1RL1, IL18R1, and IL18RAP gene cluster polymorphisms with asthma and atopy. J Allergy Clin Immunol 122: 651-654. https://doi.org/10.1016/j.jaci.2008.06.030

53. Bloodworth MH, Rusznak M, Bastarache L, Wang J, Denny JC, Peebles RS Jr (2018) Association of ST2 polymorphisms with atopy, asthma, and leukemia. J Allergy Clin Immunol 142:991-993. https://doi.org/10.1016/j.jaci.2018.03.02 0

54. Nieuwenhuis MA, Siedlinski M, van den Berge M, Granell R, Li X, Niens M, van der Vlies $P$, Altmüller J, Nürnberg P, Kerkhof $M$, van Schayck OC, Riemersma RA, van der Molen T, de Monchy JG, Bossé Y, Sandford A, Bruijnzeel-Koomen CA, Gerth van Wijk R, ten Hacken NH, Timens W, Boezen HM, Henderson J, Kabesch M, Vonk JM, Postma DS, Koppelman GH (2016) Combining genome wide association study and lung eQTL analysis provides evidence for novel genes associated with asthma. Allergy. 71(12): 1712-1720. https://doi.org/10.1111/all.12990

55. Dijk FN, Portelli MA, Shrine N, Hankinson J, Bhaker S, Ketelaar ME et al (2018) Phenotypic and functional translation of ILIRL1 locus polymorphisms in lung tissue and airway epithelium in asthma -Chapter 4. Rijksuniversiteit Groningen, Groningen, p 257

\section{Publisher's Note}

Springer Nature remains neutral with regard to jurisdictional claims in published maps and institutional affiliations.

\section{Submit your manuscript to a SpringerOpen ${ }^{\circ}$ journal and benefit from:}

- Convenient online submission

- Rigorous peer review

- Open access: articles freely available online

High visibility within the field

- Retaining the copyright to your article

Submit your next manuscript at $\boldsymbol{\nabla}$ springeropen.com 